\title{
Religiosity and Romanticism in Mandar's Love Poem Text: Stylistic Analysis
}

\author{
Nirwana Rasyid ${ }^{1}$, Mahfuddin ${ }^{2}$, Irna Fitriana ${ }^{3}$ \\ ${ }^{1}$ Bone State Islamic Institute, Indonesia \\ ${ }^{2}$ Maros Muslim University, Indonesia \\ ${ }^{3}$ Puangrimaggalatung Sengkang University, Indonesia \\ Received: November 15, 2021 \\ Received in Revised: December 24, \\ Accepted: December 31, 2021 \\ 2021
}

\begin{abstract}
The purpose of this study was to find the lexical form of religiosity and romanticism contained in the Mandar Sayang-sayang poetry. The type of research used is qualitative research, with qualitative descriptive methods. Sampling was done by using purposive sampling technique. The data collection procedure used a literature review procedure, listening method, note-taking technique, and reflective-introspective. The data analysis model used is an interactive model (interactive model). The results of the study found that the lexical containing the meaning of religiosity was found in the verse at the beginning of the text Sayang-sayang Mandar. Meanwhile, the lexical containing the expression of romanticism is found in almost all stanzas of the Mandar Sayang-Sayang text. The Mandar affectionate poetry is an expression of religiosity and the character of mutual love for fellow Mandar people and for all human beings in the world.
\end{abstract}

\section{Keywords: Religiosity, Romanticism, Sayang-sayang}

\section{Introduction}

In the midst of the rapid development of digital technology, this has an impact on the marginalization of the traditional art of Sayang-Sayang from the land of Mandar. In Mandar society, the art of Sayang-Sayang music is rarely played by the younger generation. In fact, Sayang-Sayang is a distinctive identity of Malaqbi Mandar art. In the poem Sayang-sayang contains a description of the character of the Mandar community which must be preserved by the young generation of Mandar. Characters that are passed down from generation to generation through the art of music. Regional music art that is also not owned by other regional music arts in Indonesia. The young generation of Mandar prefers to love Pop, K-Pop, Rock, and Rap songs or is willing to be enslaved by their gadgets rather than listening to SayangSayang.

The uniqueness of Sayang-sayang's art can be seen from the lyrics, which have similarities with Kalindaqdaq. Kalindaqdaq is an old form of poetry from the Mandar people. Therefore, Kalindaqdaq is considered as the forerunner of the birth of Sayang-Sayang. Sayang-sayang is the art of performing music and traditional singing of the Mandar people. As a performing art, Sayang-Sayang is played by at least 4 players, namely two musicians and two singers (a man and a woman). The singer must be one male and one female because both will reciprocate in singing like reciprocating rhymes. The two of them will return to express longing words accompanied by guitars with distinctive strums so that they sound more solemn and heartwrenching (Shaw 1988; Bernath, 2015).

The character values of the Mandar people which are inherited through the art performances of Sayang-Sayang will fade along with the low interest of the younger generation towards it. 
Excavation of character values in the art of Sayang-Sayang Mandar is very much needed to add written documentation in an effort to preserve it. The inheritance of the character values in Sayang-Sayang to the young generation of Mandar must be one of the priorities of stakeholders in West Sulawesi.

\section{Sayang-Sayang of Mandar}

Kalindaqdaq is considered to be the forerunner of the poem Sayang-Sayang. Therefore, Sayang-Sayang is considered as a poem that is sung with joy. The origin of the word Kalindaqdaq has many versions. However, Kalindaqdaq is more popularly considered to be derived from the syllables kali (gali) and daqdaq (chest). So, Kalindaqdaq can be interpreted as 'the contents of the chest' or 'the spark of feelings and thoughts expressed in beautiful sentences.

Kalindaqdaq is a Mandar poetry or pantun categorized as oral literature because it is spoken orally (Syam, 1997). This view has limited kalindaqdaq as a form of poetry or rhyme. That is, affection can be considered as a form of sung poetry. Darling as a typical art of the Mandar tribe is art with poetry full of messages, advice, religious values, romance and comedy wrapped in expressions that are both denotative and connotative (Dafid, 2019). According to Dafid (2019) the difference between Kalindaqdaq and Sayang-Sayang poetry is that there is the addition of the word Sayange sometimes at the beginning and end of the lyrics on the third line in each Sayang-Sayang verse. In addition to the addition of the word Sayange, there is also the addition of the word kaka (male) which is usually sung by the female side, while the addition of the word andi which refers to a call for a younger woman is sung by the male side in the verse of affection.

Kalindaqdaq consists of a number of stanzas. Each stanza consists of four lines with a fixed ratio of the number of syllables, namely: (a) the first line consists of eight syllables; (b) the second line consists of seven syllables; (c) the third line consists of five syllables, and; (d) the fourth line consists of seven syllables. The characteristics of Kalindaqdaq are very similar to the poetry found in the art of Sayang-Sayang. Therefore, Sayang-sayang is considered as Kalindaqdaq which is sung and accompanied by music expressing deep affection and longing.

\section{Methods}

This type of research is qualitative research. According to Moleong (2005:6), qualitative research is research that intends to understand phenomena about what is experienced by research subjects, for example behavior, perceptions, motivations, actions, and others holistically by means of descriptions in the form of words and language., in a special natural context by utilizing various scientific methods. This study uses a linguistic stylistic approach in finding the research objectives. Sampling in this study was carried out by purposive sampling. Purposive sampling technique is a technique of determining research samples with certain considerations aimed at making the data obtained more representative (Sugiyono, 2008:85). Through purposive sampling technique, eight texts of Sayang-sayang poetry were determined as research samples.

Data collection techniques in this study used literature review procedures, listening methods, note-taking techniques, and reflective-introspective (Mahsum, 2011; Sudaryanto, 2015). The data analysis model used is the data analysis model proposed by Miles and Huberman (1984), namely the interactive model. Miles and Huberman's analytical model has three components after data collection, namely: (1) data reduction, (2) data presentation, and (3) drawing conclusions or verification. Data validation in this study was carried out by data triangulation techniques. Then, the research results are presented through three methods, namely: (a) the informal method, namely the way of formulation with ordinary words that are technical in 
nature; (b) the formal method, namely the formulation method using signs, symbols, as well as various tables and charts; and (c) comparison method, namely comparing the similarities and differences of the facts and properties of the object under study.

\section{Results and Discussion}

The results of this study found several lexical forms with religious and romantic meanings in the Mandar affection text. This further strengthens the views of several groups who state that the Mandar community is a religious society that always places love for others as one of the pillars of their life.

\section{Lexical Forms of Religiosity and Romanticism in the Text of the Poem of Sayang-sayang}

\section{Lexical Forms of Religiosity in the Mandar Sayang-Sayang Poem Text}

In the text of affectionate poetry, many lexical meanings are found. Of the eight affectionate texts that were used as research samples, it was found that the lexical expressions of religious expression were Bismillah, Puang or Puange, Salama and Assalamakang. The word bismillah is found in almost all research samples. The word bismillah is used as an opening word in affection. In simple terms, the religious lexical data can be clearly classified in the following table.

Table 1. Religious Lexical Data in the Text of Sayang- Sayang Poetry

\begin{tabular}{|c|l|l|l|}
\hline No & Lexical Data & \multicolumn{1}{|c|}{ Meaning } & \multicolumn{1}{c|}{ Information } \\
\hline 1 & Bismillah & in the name of God & Islamic religious sources \\
\hline 2 & Puang & God & Being able to mean someone who is respected \\
\hline 3 & Puange & God & $+e^{\prime}$ task word: 'more affirmation' \\
\hline 4 & Lightning & Safe & Basic lexical mandar language \\
\hline 5 & Assalamakang & Safety & $a-+$ salama $(a)+-$ ang. $(n)$ \\
\hline
\end{tabular}

The following few examples can provide a brief description of lexical usage bismillah. Example (1)

Bismillah turanna elong sayange

Bismilah turanna elong bungasna panginoang

Translation:

'In the name of Allah begins the song of Sayang-sayang'

'In the name of Allah begins the song of the beginning of the game'

Example (2)

Bismillah uru sitatta' sitatta' sayange

Bismillah uru sitatta uru sioro-oroatta'

$\cdots$

Translation:

'In the name of Allah, the beginning of our meeting Sayang (dear)'

'In the name of Allah, the beginning of a face-to-face meeting'

Example (3) 


\section{Bismillah rappei puang andi}

Baca toi salama

...

\section{Translation:}

'In the name of Allah call the name of brother'

'Read also the prayer of salvation'

Observing examples (1) to (3), it shows that all three cannot be separated from the lexical bismillah 'in the name of Allah'. The lexical use of bissmillah 'in the name of Allah' is a reflection of the wishes of the author or singer, and all those involved in this activity rely solely on Allah. In other words, everything is done in the name of Allah not to anything that can associate him. Bismillah can also mean asking Allah for blessing or smoothness so that the activities of reciprocating affection go well. In the cosmology of the Mandar community, every activity of life, both worldly and oriented to the hereafter, must begin with the word bismillah. The lexical bismillah is a word that must be used by the Mandar community to start all work. Any profession owned by the Mandar people, such as fishermen, farmers, traders, and others must begin with the name of God.

In Example (3) Bismillah rappei puang andi 'In the name of Allah call name sister', the word bismillah is even repeated in the form of a command using the Mandarin language that follows it "... rappei puang andi 'call Allah's name sister'. The command to mention the name of God in starting to read the poem. Then, continued with emphasis (3) ... Read toi salama 'Also read the prayer of salvation'. So, the Mandar people place God's position as the cause of everything, humans can only try, beg and pray for the success of their intentions. Everything that happens in this world is the will of Allah SWT. Humans can only try and pray, everything will be returned to Allah SWT. In other words, the Mandar people put it in: da losong in Puang lamo disanga andang losong anna andang malluppei paranta $n a^{\prime}$ to be honest with Allah, which means to always remember and pray to Him and not forget it'. This concept is inherent in the religious life of the Mandar community.

Bismillahirrahmanirrahim Abbreviated as Bismillah, it is the pronunciation at the beginning of a letter in the Quran. This fact shows that there is a homology with Mandar's poetry of affection. Although not all Mandar's poems place the lexical bismillah at the beginning of the poem. However, these three examples can give an idea that the genetic form of syair affectionate may adopt this form. The process of assimilation of kalindaqdaq which is transformed into affection is colored with Islamic patterns. History records that kalindaqdaq as the forerunner of affection appeared for the first time during the time of Puang I Joleng as the first qadi in the Balanipa Mandar Kingdom in 1605-1633, and Mara'dia Kanna Pattang Daetta Tommuane as king (Baddulu: 1986). The king has embraced Islam, even the structure of his government includes the position of the Kadi (Royal Imam) as one of the main pillars. This shows that Islam has found a place in the life of the Mandar people at that time. Therefore, kalindaqdaq is an oral literary art that is often spoken for a specific purpose, for example entertaining, satire, giving advice (moral/ethical messages) and others.

In addition to the lexical bismillah, several times the lexical use of Puang or Puange 'God' was found, which emphasized the religiosity of the Mandar community in the text of the love poem. This is reflected in the following data.

Example (4)

Sayange salama nasang Puange 
Salama nasang ingganna mairranni

Translation:

Dear all, God bless you

Congratulations to all listeners

Example (5)

Mua salama bandi Puange

Mua salama bandi jalanna penginoang

Sayange naringgannai tori'mo

Translation:

If everything is safe, $\mathrm{O}$ Allah

If everyone is happy with the game

Will add more (pity)

Example (6)

Utoe dai tattoyang Puang

Utoe dai tattoyang

Utuyuang tarrappe Puang

...

Translation:

I hang my hope Lord

I hang my hope

I tie God tightly

The lexical form of puange has undergone a morphological process from the word puang (n) 'God' + e. The particle e is an assignment word which means an affirmation of the word it follows, namely God. Lexical Puang and Puange in the above verse refers to something that is believed, worshiped, and worshiped by the writer or singer of the poem. In examples (4) to (6) describe the lexical use of Puang or Puange 'God' as the main reference for human salvation and ideals. Although in the life of the Mandar community, the lexical puang also correlates with humans, namely people who are given awards. For example, parents who are not known, people who are respected in society, or people who have high positions in the social life strata of the Mandar community. Meanwhile, in the lexical Mandar nobility strata, puang is usually given to customary aristocrats, namely the hadat descendant group. However, in this verse the reference to Puang and Puange is Allah SWT.

So strong is submission to Allah SWT, this verse implements it in the lexical tori'mo 'have mercy'. It can be seen in example (5) ... Sayange naringgannai tori'mo 'There will be more pity (pleading)'. This lexical is an exclamation of pity, or of asking for pity. The desire to get mercy from God so that the game can run well. That is, humans who manage work, play, try, and work but their success will be returned to Allah SWT. This also proves that the humility 
of a human being to serve himself. This verse has illustrated that Mandar people use art as a form of conveying moral values that civilized humans must possess.

Furthermore, the lexical Salama 'congratulations' and Assalamakang 'safety' are also often found in the text of affectionate poetry as a manifestation of this religious character. The use of the lexical forms of salama and assalamakang can be examined in the following verses.

Example (7)

Namembura salama sayange

Namembura salama turunang di'e mae

Sayange anna salama kandiu

Translation:

Congratulations sister

Congratulations to hometown here

Sayang agar selamat adikku

Example (8)

... Sayange assalamakang

Assalamakang todiq di rannuang

Bismillah uwiqwi lawe kakak

Translation:

Sayang safety

The safety we hope for

Bismillah from my lips

Example (9)

Mua na salama bandi puange

Salama bandi jalanna panginoan

Sayange na digannai todzi mo

Translation:

If everything is safe, $\mathrm{O}$ Allah

If everyone is happy with the game

Will add more (pity)

The form of the word assalamakang (n) 'safety' comes from the morphological process a- + salama (a) + -ang. In this process there is a gemination event or an elongation of the consonant phoneme (s) so that it becomes (ss) in assalamakang. The same morphological process occurs in the word asugiang $(\mathrm{n}) \rightarrow \mathrm{a}+$ sugi $(\mathrm{a})+-$ ang, the word acangngoang $(\mathrm{n}) \rightarrow \mathrm{a}-+$ cangngo (a) +- ang and others. However, the words asugiang and acangngoang do not cause a gemination 
process. Lexical salama (a) can be interpreted as freedom from a person from disaster, disturbance, damage or danger. On the other hand, the word assalamakang (n) is defined as a condition or situation that is protected from calamity, disaster, or danger. The morphological process that changes the form of an adjective into a noun form. The lexical use of salama with adjective classification is exchanged with the form of assalamakang in the noun category, which can be interpreted as an effort to concretize the meaning of salvation in the listener. This means that safety for the community must be their priority. Cannot be underestimated or trivial.

Furthermore, the lexical salama and assalamakang are used to show that the Mandar people always prioritize the state of being free from calamity and disaster. Their main priority is to avoid distractions, obstacles, or problems that may arise in a job. Then, safety is expected to cover the whole community, not individual. This is reflected in: namembura salama derivatang di'e mae 'a string of congratulations to my hometown here'. So, the request for safety is intended for the entire village or community, not only for certain individuals or groups. This explanation is made clear through the Mandar proverb: Yes, pap pairs of poles in Iya pappasang pole di neneta: tuo'o dai' marendeng, salama' tuo mi' apa pa'ulleanna batang. That is, as for the ancestral will: live safely, live safely according to one's ability. It is advisable to live in common safety, not to push yourself to reach the impossible.

\section{The Lexical Form of Romanticism in the Poem of Sayang-Sayang}

The reduplicated form of Sayang-Sayang comes from the word Sayang 'love, affection, like, or attached. Usually gets emphasis at the end of the word through the task word $\mathrm{e} \rightarrow$ dear + -e $\rightarrow$ deare. The task word e in Sayange shows an affirmation of the meaning of affection, likes, loves, or loves which is the referent of the word. This word of affection is reduplicated into affection, a form of poetry that is sung in the form of a song composed of the Kalindaqdaq poetry of the Mandar community. The meaning of the intensity is more than the word love, the value of the taste is increased to love. That is, the word affection 'like, love, or love' is made more: like, love, love, or cherish. Meanwhile, pasayang-sayang is derived from the addition of the prefix pa + Sayang-sayang to produce a meaning that refers to the performer of the art or the art of Sayang- Sayang itself. The prefix pa- is used to form nouns in Mandarin. The lexical use of Sayange can be observed in the following example.

Example (10)

Rapamma tuo tammate sayange

Rapamma tua tammate sannantamma sannamma'

Sayange apa malaimi kandi'u

Apa malaimi tau silappa' loa

Translation:

As if my life without death

As if my life without death filled with pleasure and displeasure

It's a shame we got sister

We can speak

Example (11)

Naurappei tunau sayange 
Naurappei tunau disioro orota

Sayange dapa manini kandi'u

Dapa manini manoso diwoe'na

Translation:

Don't call your insults dear

Don't mention your humiliation in front of me

Honey, don't let it come later brother

Don't regret later

Example (12)

Diang tau diate kamau kakaq

Eloqmu di watau

Sayangnge tarrua sita

Tarrua sipau

Translation:

There is someone who is captivated in my father's heart brother

Your love for me

Too bad we never met

Never speak

The lexical use of Sayange is found in almost all of the verses in the text of the affectionate poetry used as the sample of this research. Examples (10) to (11) are three illustrations of the lexical use of Sayange in the text of Sayang-Sayang. This proves that the lexical Sayange 'sweetheart' which is emphasized through the word task e is the central point of this art. Lexical affection is a representation of expressing sincere affection for fellow human beings. The disclosure of the depth of the meaning of Sayange is also strengthened by the presence of kakaq and kandi (u) lexical in the example stanza above. For example, dear malaimi kandi'u 'darling we have a sister' or deare dapa manini kandi'u 'darling, don't let it be, sister'.

The word kakaq 'kakak' is a greeting for older people and kandiu 'my sister' is used as a greeting for younger people. So, the principle of loving to younger people or respecting and loving parents is illustrated in the text. Even though the context in the text of this affectionate poem focuses more on the love of young people. However, this text actually also reaches out to compassion for fellow human beings. The message in the Mandar proverb will confirm this trait: dao situna-tunai parammurupa tau, sitteteng nasangdi tau to na padiang Puang 'don't insult each other between human beings, we are all human beings created by God'. This is also clarified in the following proverb: mua' cappu' in sayammu siri'mu mbei, mua' siri' balala tomi diang dua-a rakke'mu lao di Puang 'if love has run out, please help pick up shame, if Even the shame is gone. Hopefully you still have the fear of Allah'. So, compassion is always used as a 
foothold for action and when affection has run out, shame must take precedence in acting to get to the fear of God. Mandar people are prohibited from insulting other people but call for mutual help among humans as God's creation.

In addition to lexical affection, the expression of romanticism can also be seen in several uses of metaphors that correlate with affection. The following table can provide an overview of the use of some of these metaphors.

Table 2. Data on the Use of Romanticism Metaphors in the Text of the Poem of Sayangsayang

\begin{tabular}{|c|l|l|l|}
\hline No & \multicolumn{1}{|c|}{ Date Metaphor } & \multicolumn{1}{c|}{ Translation } & \multicolumn{1}{c|}{ Meaning } \\
\hline 1 & $\begin{array}{l}\text { Rapamma tua tammate } \\
\text { sannangtamma sa nannang } \\
\text { ma }\end{array}$ & $\begin{array}{l}\text { It's as if life doesn't die that's not } \\
\text { covered with joy and } \\
\text { displeasure. }\end{array}$ & Suffering from inner birth \\
\hline 2 & $\begin{array}{l}\text { Malotoppai puteang } \\
\text { mapute kalloaya }\end{array}$ & $\begin{array}{l}\text { If the black heron crow turns } \\
\text { white }\end{array}$ & Impossible \\
\hline 3 & $\begin{array}{l}\text { Mate nandea got loka } \\
\text { natitto kalapuang }\end{array}$ & $\begin{array}{l}\text { Died eaten by a rotten disease } \\
\text { banana tree bitten by a turtle }\end{array}$ & Suffering from inner birth \\
\hline 4 & $\begin{array}{l}\text { Na masara sau wanda di } \\
\text { lololanna uwai }\end{array}$ & $\begin{array}{l}\text { My problem is staying there } \\
\text { following the flow of water. }\end{array}$ & $\begin{array}{l}\text { Love remains for the } \\
\text { woman }\end{array}$ \\
\hline
\end{tabular}

This can be seen in the following example.

Example (13)

Rapamma tuo tammate sayange

Rapamma tua tammate sannattamma sa' namma'

sayange apa malaimi kandi'u

apa malaimi tau silappa' loa

Translation:

It's like life doesn't even die, it's not dear.

It's as if life doesn't die that's not covered with joy and displeasure.

It's a shame we got our sister.

Already we can speak the word

Example (14)

\section{Malotoppai puteang kandi'u}

Malotoppai puteang mapute kalloaya

Sayange anna pinrai todzi'mo

Anna pinrai cinnau diwatammu

Translation:

If the stork has been black 
If the black heron crow turns white

Honey then change pity

Then it changed my love for you

Example (15)

Mate nandea sai loka sayange

Mate nandea sai loka natitto kalapuang

Sayange sangga' batammu ya todzi

Sangga' batammu dilalang di ateu

Translation:

Died eaten by rotten disease banana tree dear

Died eaten by a rotten disease banana tree bitten by a turtle

It's just a pity you.

You are the only one in my heart.

Example (16)

Na masara sau wanda sayange

Na masara sau wanda di lololanna uwai

sayange i'da maupa' kasi'na

i'da maupa' masara dipottana

Translation:

My problem stays there baby

My problem is staying there following the flow of water.

My dear is unlucky pity

I'm unlucky about my problems in this place.

The expression in the example (13) rapamma tuo tammate darlinge, rapamma tua tammate sannattamma sa' namma 'as if you don't live, you don't have to die, you don't care, you don't live, you don't even die, you're not filled with joy and displeasure' is a reflection of the restlessness of one's heart towards others. others. This form is a metaphor that someone who bears the burden of unrequited affection will have feelings like this. A person's feelings are described as being between life and death when living without reciprocal love. In fact, the form and taste of death has never been passed by the author or the singer of love. So, this expression is used as a metaphor as a manifestation of the depth of a man's feelings for the woman he loves. 
Furthermore, example (14) reveals something similar in: malotoppai puteang kandi'u, malotoppai puteang mapute kalloaya 'if the stork is black, if the stork is black the crow turns white'. The stork known by the Mandar people is white. Nothing in their life has storks violated their nature with black fur. Likewise with the crow, the Mandar people know that this bird is black in color. So, if the white-feathered crow is a form of impossibility and against destiny that already exists. This metaphor means that it is impossible to change that love and affection for other women.

Then, example (15) is a metaphor for expressing a death oath for the sincerity of a man's love for a woman. This is reflected in: mate nandea sai loka Sayange, mate nandea sai loka natitto kalapuang 'die of banana tree rot, dear banana tree rot, and turtle bites'. Banana stem rot disease is known in the Mandar community with the compound word sai loka. This verse uses the metaphor of banana stem rot disease which is impossible to infect humans. Furthermore, if banana stem rot disease attacks, the leaves that are still green and upright gradually turn yellow, the stem rots, the fruit turns yellow and black, the weevil and roots turn brown and blacken. Then, the banana tree will dry up and die. Sai loka's death oath is expected to reflect the seriousness of a man's love for the woman he loves. In other words, the man swears that he will die similar to the process of dying from a rotten banana tree trunk if he tells lies.

In example (16) the use of metaphorical forms in: na masara sau wanda Sayange, na masara sau wanda di lololanna uwai 'My problems stay there dear, my problems stay there with the flow of water'. The lexical na functions as a task word which means I or I. Lexical masara comes from a morphological process: ma + sara 'problem/problem'. The prefix ma- $\rightarrow$ masara functions as an active form parallel to me- and ber- in Indonesian. That is, the problem or problem faced by the me / my / me is a form that was born in him. The problem kept roiling in him so that he called it in lololanna uwai 'like following the flow of water'. The problem is not a small problem but something very heavy to bear. The problem or problem in question is his love for a woman.

\section{The Character of the Mandar Community in the Text of the Poem Sayang-sayang}

From the description of the lexical form of religious and romanticism in the Mandar affectionate text, it is clear that the Mandar community is a religious community, holding firmly to morality, belief, and ethics in maintaining relationships with God, humans and nature. The religious values of the Mandar people reflect their firmness in holding their beliefs as Muslims. The rules in Islamic law are adopted to serve as social patrons. The teachings of Islam become their guide in every behavior behavior. Therefore, belief in Allah SWT. always the mainstay. Submission to the creator will be placed first before doing all the activities of the world. This can also be seen in several Mandar tradition rituals that are thick with Islamic nuances, for example makkuliwa 'ritual before the use of new goods', mappandre sorong 'fisherman's thanksgiving ritual', mappa'dendang 'ritual welcoming the harvest', massorong lopi-lopi 'ritual reject reinforcements', and so on. These rituals contain prayers of salvation that are offered to Allah SWT. so that Mandar people both individually and collectively are protected from all disasters. In turn, every practice in traditional rituals leads the Mandar community into a religious and religious community.

Furthermore, the text of affection shows the nuances of compassion, namely a sense of affection for fellow human beings. Mandar society places humans as creatures who should be respected, not humiliated. Although in Mandar society there is also a social stratification that has existed since ancient times. However, respect for fellow human beings is still used as the main foundation in relating to each other. Even though someone has the title of the highest nobility (mara'dia) but he must respect other humans who are lower in rank. Such behavior further thickens their position in Mandar society as nobles who can be used as role models for

Copyright $\odot$ 2022, Journal of Asian Multicultural Research for Social Sciences Study, Under the license CC BY-SA 4.0 
their character and behavior. If the aristocrat behaved otherwise, society often dubbed him lexically mabangka or borro 'arrogant'. This lexical certainly has a negative connotation which will have a negative impact on people's appreciation of him. So, the reflection of affection for fellow human beings in the text of affectionate poetry leads to the nature of being polite and courteous to others.

The art of affection also represents the malaqbiq character of the Mandar community. In art, social identity is not released as the basis for Mandar people to interact with one another. The concept of malaqbiq as a way of life and basic conventions for interacting with family, neighbors, and the wider community in the Mandar community is also presented in the text. The Mandar community views that one of the meanings of malaqbiq is: expertayai to tondodai, pakalaqbiq si patummu, assayanni to tondonaung 'respect those above us, glorify people equal to us, and love those below us. The nuances of compassion contained in the text of the love poems prove that there are residual malaqbiq values in this art.

\section{Conclusion}

This study found that lexical religious expressions, such as bismillah, puang or puange, salama and assalamakang are reflections of the religious and religious nature of the Mandar community. Meanwhile, the expression of romanticism is dominated by the lexical form of Sayange and several forms of metaphor, for example rapamma tuo tammate sannattamma sa namma 'as if life does not die nor is it filled with feelings of pleasure and displeasure', malotoppai puteang mapute kalloaya 'if the crane is black the crow changes white color', mate nandea sai loka natitto kalapuang 'died by a banana tree rot disease bitten by a tortoise', na masara sau wanda di lololanna uwai 'my problems keep going there following the flow of water' is a representation of the values and character to love each other from Mandar people. The reflection of values and characters in the text of the Mandar affectionate art leads to the concept of malaqbiq as the social identity of the Mandar community. In addition to its recreational function, this art is one of the media to internalize the identity of malaqbiq in Mandar society.

\section{References}

Bernath, V. (2015). Social Identity and Biological Identity. Translating the Americas, 3.

Dafid, M. (2020). Analisis Makna Syair Sayang-Sayang Suku Mandar Sulawesi Barat Melalui Pendekatan Hermeneutika. Bahasa Dan Sastra, 5(1).

Mahsun, M. S. (2005). Metode penelitian bahasa: tahapan strategi, metode dan tekniknya. PT RajaGrafindo Persada.

Moleong, L. J. (2005). Metodologi kualitatif. Edisi Revisi. Bandung: PT Remaja Rosdakarya.

Shaw, T. A. (1988). Emerging persons: youth subculture, social identity and social mobility in an urban Chinese setting (Doctoral dissertation, Columbia University).

Sudaryanto, S. (2015). Metode dan aneka teknik analisis bahasa. Yogyakarta: APPTI.

Sugiyono, D. (2013). Metode penelitian pendidikan pendekatan kuantitatif, kualitatif dan R\&D. digilib.unigres.ac.id

Syam, S. (1997). Bungai RAMPAI Kebudayaan Mandar dari BALANIPA Cet. I. Tinambung: Yayasan Mahaputra Mandar. 